\section{BRAZIULIAN JOURNAL \\ OF MEDICAL AND BIOLOGICAL RESEARCH}

www.bjournal.com.br
ISSN 1414-431X

Volume 45 (12) 1102-1340 December 2012

\section{BIOMIDICAL SCIENCES}

AND

CLINICAL INVESTIGATION

Braz J Med Biol Res, December 2012, Volume 45(12) 1127-1134

doi: 10.1590/S0100-879X2012007500160

The RecX protein interacts with the RecA protein and modulates its activity in Herbaspirillum seropedicae

C.W. Galvão, E.M. Souza, R.M. Etto, F.O. Pedrosa, L.S. Chubatsu, M.G. Yates, J. Schumacher, M. Buck and M.B.R. Steffens

The Brazilian Journal of Medical and Biological Research is partially financed by

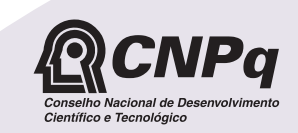

Ministério
da Ciência e Tecnologia

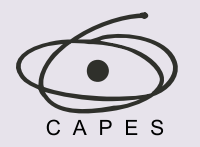

Ministério da Educação
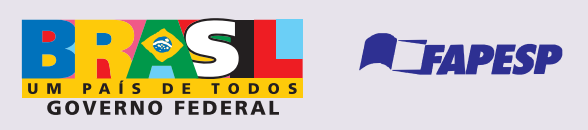

Institutional Sponsors

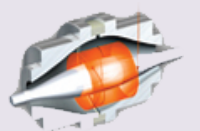

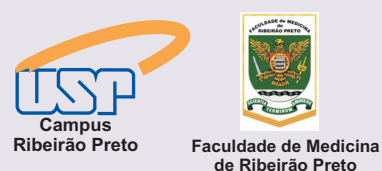

de Ribeirão Preto
diculdade de

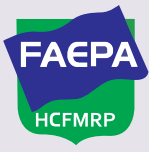

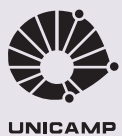

UNICAMP
Ф SHIMADZU lore High - Performance MS Orbitrap Technology In Proteomics \& Metabolomics analitica Thermo 


\title{
The RecX protein interacts with the RecA protein and modulates its activity in Herbaspirillum seropedicae
}

\author{
C.W. Galvão ${ }^{1}$, E.M. Souza², R.M. Etto ${ }^{1}$, F.O. Pedrosa², L.S. Chubatsu², \\ M.G. Yates $^{2}$, J. Schumacher ${ }^{3}$, M. Buck ${ }^{3}$ and M.B.R. Steffens ${ }^{2}$ \\ 1Departamento de Biologia Estrutural, Molecular e Genética, \\ Universidade Estadual de Ponta Grossa, Ponta Grossa, PR, Brasil \\ ${ }^{2}$ Departamento de Bioquímica e Biologia Molecular, Universidade Federal do Paraná, \\ Curitiba, PR, Brasil \\ ${ }^{3}$ Department of Life Sciences, Imperial College London, London, UK
}

\begin{abstract}
DNA repair is crucial to the survival of all organisms. The bacterial RecA protein is a central component in the SOS response and in recombinational and SOS DNA repairs. The RecX protein has been characterized as a negative modulator of RecA activity in many bacteria. The recA and recX genes of Herbaspirillum seropedicae constitute a single operon, and evidence suggests that RecX participates in SOS repair. In the present study, we show that the $H$. seropedicae RecX protein (Rec $\left.X_{H s}\right)$ can interact with the $H$. seropedicae RecA protein $\left(R_{e c} A_{H s}\right)$ and that RecA $A_{H s}$ possesses ATP binding, ATP hydrolyzing and DNA strand exchange activities. Rec $\mathrm{X}_{\mathrm{Hs}}$ inhibited $90 \%$ of the RecA $\mathrm{Hs}_{\mathrm{s}}$ DNA strand exchange activity even when present in a 50 -fold lower molar concentration than RecA $\mathrm{Hs}_{\mathrm{s}}$. RecA $\mathrm{H}_{\mathrm{Hs}}$ ATP binding was not affected by the addition of RecX, but the ATPase activity was reduced. When $\mathrm{Rec}_{\mathrm{Hs}}$ was present before the formation of RecA filaments (RecA-ssDNA), inhibition of ATPase activity was substantially reduced and excess ssDNA also partially suppressed this inhibition. The results suggest that the Rec $\mathrm{X}_{\mathrm{Hs}}$ protein negatively modulates the RecA $\mathrm{Hs}_{\mathrm{s}}$ activities by protein-protein interactions and also by DNA-protein interactions.
\end{abstract}

Key words: RecA; RecX; Herbaspirillum seropedicae; SOS repair

\section{Introduction}

Bacterial genomic DNA is constantly subject to chemical and physical damage. The repair of such damages is essential since DNA is the template for its own duplication as well as the production of diverse types of RNA and proteins (1). Specialized enzymatic complexes are designed to avoid genetic alterations or to reduce their frequency (2).

RecA is a key enzyme in the DNA repair process in bacteria. RecA promotes the expression of proteins involved in the non-mutagenic and mutagenic DNA repair by inducing LexA repressor autocleavage (3) and promotes recombinational DNA repair by catalyzing the DNA strand exchange reaction (4). In addition, RecA-ATP binds to the UmuD' ${ }_{2} \mathrm{C}$ complex to form the active PolV polymerase responsible for the DNA translesion synthesis or SOS mutagenesis (5).

The RecA protein is highly conserved among bacteria, and homologues of RecA are also found in bacteriophages, Archaea and Eucarya (4). RecA activity is induced upon binding to single-stranded DNA(ssDNA), a process named nucleation, followed by rapid 5' to 3' extension, in such a way that additional RecA monomers are only added at the 3 ' filament end (6). Disassembly of RecA filaments is also unidirectional (5' to 3') and end-dependent, occurring on the end opposite to that where filament extension occurs (6-8). To mediate a broad spectrum of biological events the RecA protein needs to be bound to the DNA and also requires the participation of other proteins that interact with RecA and/ or modulate RecA activity (RecFOR, RecBCD, SSB, LexA, UmuD, Dinl, RdgC, PsiB, and RecX proteins) (9-15).

The RecX protein has attracted much interest because the recX gene is located downstream from recA, forming a single operon in many bacteria (16-21). Knock-out mutants

Correspondence: C.W. Galvão, UEPG/SEBISA/DEBIOGEM, Av. General Carlos Cavalcanti, 4748, 84030-900 Ponta Grossa, PR, Brasil. Fax: +55-42-3220-3102. E-mail: carolinawgalvao@hotmail.com

Received May 26, 2012. Accepted August 14, 2012. Available online October 15, 2012. Published December 17, 2012. 
of recX caused a great variety of phenotypes associated with RecA functions (17-26). Protein analyses revealed that RecX interacts directly with the RecA protein and that RecX negatively modulates the recombinase, ATPase, and coprotease activities of RecA in Mycobacterium tuberculosis (27), Escherichia coli (25) and Deinococcus radiodurans (26). These inhibitory activities are performed by blocking RecA filament extension $(28,29)$. In vivo studies in Neisseria gonorrhoeae (24) and Xanthomonas oryzae pv. oryzae (18) suggested an alternative positive modulation of RecA by RecX.

In Herbaspirillum seropedicae the recAX genes constitute a single operon. Physiological analyses of the mutant recX of $H$. seropedicae have suggested the participation of the RecX protein in the SOS response and homologous recombination (21), indicating involvement of the RecX protein in the modulation of RecA activity. In this report, we demonstrate that the $H$. seropedicae $\operatorname{RecX}\left(\operatorname{Rec}_{H s}\right)$ interacts with the homologous RecA protein $\left(\operatorname{Rec} A_{H s}\right)$ and inhibits RecA recombinase and ATPase activities but not ATP binding activity. These results, together with previous reports, which showed that RecX is capable of forming DNAprotein complexes, suggest that the mechanism of RecA modulation by RecX might involve not only protein-protein interactions but also DNA-RecX interactions.

\section{Material and Methods}

\section{Plasmid construction}

The fragment Ndel/Xhol containing the recX gene of $H$. seropedicae from the plasmid pCWG3 (30) was cloned into the Ndel/Sall digested vector pT7-7 (New England Biolabs, USA), yielding the plasmid pXT7. The recA gene of $H$. seropedicae was amplified using the plasmid pBMR503 (31) as the template together with the primers recA1 (5'-GAGAGAG ACATATGGACGA-3') and recA2 (5'-AGGGAGCGGATCC TCAGGAGGCTTTCG-3'). The $\mathrm{Ndel}$ and $\mathrm{BamHI}$ sites (underlined) were used to clone the 1.1-kbp PCR fragment into the Ndel/BamHI-digested vector pET28b+HMK (constructed and donated by P. Bordes, Université de Toulouse, France), yielding the plasmid pAETWT-HMK. The amino-terminal hexaHis sequence of the vector was deleted by digesting with Ndel and Xbal enzymes, producing the plasmid pCWG9. The His-tagged RecX (RecXHis), native RecX, aminoterminal His-tagged $\operatorname{RecA}$ (RecAHis) and the native RecA proteins were overexpressed from the plasmids pCWG3, pXT7, pAETWT-HMK, and pCWG9, respectively.

\section{Protein expression}

E. coli strains BL21 (ADE3) pLyS or B834 (DE3) (Merck $\mathrm{KGaA}$, Germany) containing the correct plasmid were grown in Terrific Broth medium (32) on a rotary shaker to an $\mathrm{OD}_{600}$ of 0.3 at $37^{\circ} \mathrm{C}$. At this point, the culture was maintained at $25^{\circ} \mathrm{C}$ for $30 \mathrm{~min}$ before adding $1 \mathrm{mM}$ isopropyl- $\beta$-D- thiogalactopyranoside and incubated for a further 3-4 h. Cells were harvested by centrifugation and stored at $-20^{\circ} \mathrm{C}$. All subsequent purification steps were at $4^{\circ} \mathrm{C}$.

\section{Native RecA protein purification}

The native RecA protein was purified as described by Steffen and Bryant (33) with a few modifications. Briefly, the soluble protein extract was treated with polymin-P, followed by ammonium sulfate (four times, at 5, 34, 54 , or $58 \%$ saturation). The final sample was dialyzed against buffer A (10 mM Tris- $\mathrm{HCl}$ pH 8.0, $50 \mathrm{mM} \mathrm{NaCl}$, and $1 \mathrm{mM}$ DTT) containing $10 \%$ glycerol and then loaded onto a DEAE sepharose column $(28 \mathrm{~mL}, 1.6 \times 21 \mathrm{~cm}$, GE Healthcare, USA). After being submitted to an $\mathrm{NaCl}$ gradient $(0.05-1 \mathrm{M})$ in buffer A containing $10 \%$ glycerol, the fractions containing the native RecA were dialyzed and stored at $-80^{\circ} \mathrm{C}$.

\section{Native RecX protein purification}

The frozen cells were thawed on ice, suspended in 25 $\mathrm{mL}$ buffer A containing $10 \%$ glycerol and $1 \mathrm{mM}$ phenylmethylsulfonylfluoride and lysed by sonication (Ultrasonic Processor XL, Qsonica, LLC, USA) on ice. The soluble protein extract was loaded onto an SP-sepharose column (50 mL, 1.6 x $25.5 \mathrm{~cm}$, GE Healthcare). After being submitted to an $\mathrm{NaCl}$ gradient $(0.05-1 \mathrm{M})$ in buffer A containing $10 \%$ glycerol the fractions containing the native RecX were dialyzed and stored at $-80^{\circ} \mathrm{C}$.

\section{His-tagged RecA and RecX proteins purification}

The frozen cells were thawed on ice and lysed in a cell disruptor (Constant Systems Ltd., UK) in 25-50 mL buffer $\mathrm{A}_{\mathrm{NI}}\left(25 \mathrm{mM} \mathrm{NaH}_{2} \mathrm{PO}_{4} \mathrm{pH} 7.0,5 \%\right.$ glycerol, and $0.5 \mathrm{M}$ $\mathrm{NaCl}$ ) containing a cocktail tablet of protease inhibitors ( $\mathrm{F}$. Hoffmann-La Roche Ltd., Switzerland, Cat. No. 11836153001). The soluble protein extract was loaded onto a $5 \mathrm{~mL}$ Hi-Trap Chelating column (GE Healthcare) charged as indicated by the manufacturer. After being submitted to an imidazole gradient (0.04-0.8 M) in buffer $A_{N I}$, the fractions containing the RecAHis or RecXHis protein were dialyzed and stored at $-80^{\circ} \mathrm{C}$.

\section{$\mathrm{Ni}^{2+}$ bead immobilization}

RecXHis $(\sim 5 \mu \mathrm{M}-8.4 \mu \mathrm{g})$ or DraGHis $(\sim 2.5 \mu \mathrm{M}-8.4$ $\mu \mathrm{g})$ was immobilized on Sepharose-chelating FF beads $\left(\mathrm{Ni}^{2+}\right.$ beads, $\left.15 \mu \mathrm{L}\right)$ following manufacturer instructions (GE Healthcare). After centrifugation (500 g, $5 \mathrm{~min}$ ) and washing the pellet with buffer A containing $5 \%$ glycerol, $2.5 \mu \mathrm{M}(8.4 \mu \mathrm{g})$ native RecA was added. The system was then incubated for a further $30 \mathrm{~min}$, centrifuged (500 g, 5 $\min$ ) and the pellet was washed with buffer A containing $5 \%$ glycerol. The immobilized proteins were eluted by the addition of buffer A containing $5 \%$ glycerol and $0.5 \mathrm{M}$ imidazole. An aliquot from each fraction was analyzed by SDS-PAGE and the protein content visualized by staining with Coomassie blue. 


\section{DNA strand exchange assay}

The DNA strand assay was adapted from Drees et al. (28). The RecA protein $(6.7 \mu \mathrm{M})$ was pre-incubated with $22.6 \mu \mathrm{M} \phi \mathrm{X} 174$ circular ssDNA (New England Biolabs) and an ATP-regenerating system [10 U/mL pyruvate kinase (Sigma-Aldrich, USA) and $5 \mathrm{mmol}$ phosphoenolpyruvate (Sigma-Aldrich)] for $10 \mathrm{~min}$ in $20 \mu \mathrm{L}$ buffer $\mathrm{E}(25 \mathrm{mM}$ Tris-acetate $\mathrm{pH} 7.5,1 \mathrm{mM}$ DTT, 5\% (w/v) glycerol, $3 \mathrm{mM}$ potassium glutamate, and $10 \mathrm{mM}$ magnesium acetate) at $37^{\circ} \mathrm{C}$. SSB protein $(2 \mu \mathrm{M})$ and ATP $(3 \mathrm{mM})$ were then added, followed by another 6 min of incubation. The RecX protein was added at the concentrations given in the figure legends, incubated for 6 min before the addition of $15.6 \mu \mathrm{M} \phi \mathrm{X} 174$ linear double-stranded DNA (dsDNA) and incubated for a further 90 min before stopping the reaction by adding $5 \mu \mathrm{L}$ equilibrated phenol and $3 \mu \mathrm{L} \mathrm{10 \%} \mathrm{SDS} \mathrm{to} \mathrm{each} \mathrm{reaction.}$ Samples were electrophoresed on $0.8 \%$ agarose gels in TAE buffer, stained with ethydium bromide, and exposed to ultraviolet light. The $E$. coli $\operatorname{Rec} A\left(\operatorname{Rec}_{E c}, G E\right.$ Healthcare) was used as control.

\section{ATP binding assay}

ATP binding assays by UV crosslinking were conducted essentially as described by Schumacher et al. (34) with some modifications. Standard reaction mixtures $(20 \mu \mathrm{L})$ containing ATP binding buffer (20 mM Tris- $\mathrm{HCl}$ pH 7.5, 20 $\mathrm{mM}$ potassium chloride and $10 \mathrm{mM}$ magnesium chloride), $\operatorname{Rec}_{\mathrm{Hs}}(2.5 \mu \mathrm{M})$ and/or $\operatorname{Rec} X_{\mathrm{Hs}}(2.5$ or $10 \mu \mathrm{M}), 6.5 \mu \mathrm{M}$ $\phi X 174$ circular ssDNA and $37 \mathrm{kBq}\left[\alpha^{32} \mathrm{P}\right]-A T P(111 \mathrm{TBq} /$ $\mathrm{mmol})$ were placed on a glass plate, which was covered with a plastic film (Parafilm ${ }^{\mathrm{TM}}$ ) and maintained on ice. The reactions were then irradiated with a UV lamp (254 nm, UVG-54; UVP, USA) at a distance of $3 \mathrm{~cm}$ for $20 \mathrm{~min}$ and quenched by the addition of $3 \mu \mathrm{L} 6 \mathrm{XSDS}-\mathrm{PAGE}$ loading dye. After heating at $95^{\circ} \mathrm{C}$ for $3 \mathrm{~min}$, the samples were analyzed on SDS-PAGE gels (12.5\%) (35). Gels were stained with Coomassie blue to detect the proteins and, after drying, the cross-linked products were visualized with a FLA-5000 Phosphor Imager and the images were analyzed using the AIDA densitometry program.

\section{ATPase assay}

ATPase assays were performed in ATPase buffer (25 $\mathrm{mM}$ Tris-acetate $\mathrm{pH}$ 7.5, $1 \mathrm{mM}$ DTT, $3 \mathrm{mM}$ potassium glutamate, $10 \mathrm{mM}$ magnesium acetate and $5 \%(\mathrm{w} / \mathrm{v})$ glycerol), with $\phi X 174$ circular ssDNA (44 $\mu \mathrm{M}$, unless otherwise indicated), RecA protein (1.2 $\mu \mathrm{M})$, RecX protein $(5 \mu \mathrm{M}$, unless otherwise indicated), SSB protein $(0.2 \mu \mathrm{M})$, and labeled ATP $(0.4 \mathrm{mM})$. The components of each reaction system $(20 \mu \mathrm{L})$ are described in the legends to the figures. Reactions were started by the addition of the SSB protein and labeled ATP, which was prepared by mixing $1.1 \mathrm{MBq}\left[\alpha^{32} \mathrm{P}\right]-A T P$ (111 TBq/mmol), $50 \mu \mathrm{L}$ cold ATP (4 mM) and $97 \mu \mathrm{L}$ ultrapure water. Reactions were stopped at different times (see figure legends for details) by the addition of $10 \mu \mathrm{L} 2 \mathrm{M}$ cold formic acid to an aliquot $(2 \mu \mathrm{L})$ of the reaction and kept on ice. Aliquots ( 1 or $2 \mu \mathrm{L}$ ) of each reaction were analyzed by thin layer chromatography as described by Bochner and Ames (36). The amounts of labeled ATP and ADP present in each reaction were determined after imaging with a FLA-5000 Phosphor Imager and analyzed as before.

\section{Results}

\section{Interaction of $\boldsymbol{H}$. seropedicae RecA and $\operatorname{RecX}$ proteins}

A bead immobilization assay was carried out to determine whether the RecA and RecX proteins of $H$. seropedicae could interact. Co-elution of tethered RecXHis and native RecA from Sepharose beads indicated interaction of the two proteins (Figure 1A). In contrast, when the DraGHis protein of Azospirillum brasilense was bound to the Sepharose beads it failed to bind RecA (Figure 1B). Native RecA was unable to bind to the beads per se. These results suggest a specific binding of RecX to RecA in vitro.

\section{RecX prevents strand exchange promoted by RecA}

Since $\operatorname{Rec}_{\mathrm{Hs}}$ protein was shown to bind high and low molecular weight DNA molecules (30; data not shown), we examined the effect of RecX on RecADNA strand exchange activity. In this reaction, the circular ssDNA (S1) and the homologous linear dsDNA (S2) are recombined to form a nicked circular dsDNA $(P)$ and a linear ssDNA as products. The SSB was included in the reaction to melt out the secondary structure in the circular ssDNA substrate and to stabilize the linear ssDNA product. The $\mathrm{RecA}_{\mathrm{Hs}}$ was able to promote strand exchange (Figure 2A, lane 1). The addition of $0.05 \mu \mathrm{M} \mathrm{Rec} X_{\mathrm{Hs}}$ protein to the $\mathrm{Rec}_{\mathrm{Hs}}$ reaction resulted in a substantial decrease of product formation (Figure 2A, lane 2) and the reaction was abolished with $2 \mu \mathrm{M} \operatorname{Rec}_{\mathrm{Hs}}$ (Figure 2A, lane 5). The $\mathrm{Rec}_{\mathrm{Hs}}$ protein also inhibited the RecA $\mathrm{Ec}_{\mathrm{Ec}}$-mediated DNA strand exchange (Figure 2B). The inhibition of the RecA DNA strand exchange activity by substoichiometric RecX concentrations suggests that RecX does not have to interact with every RecA monomer to exert its effect.

\section{RecX does not change RecA ATP binding activity}

To test whether RecX influences the binding of ATP to RecA, [ $\left.{ }^{32} \mathrm{P}\right]$-labeled ATP was incubated with RecA $A_{H s}$ in the presence or the absence of $\operatorname{Rec}_{\mathrm{Hs}}$, and the bound [ $\left.{ }^{32} \mathrm{P}\right]-$ labeled ATP was subsequently cross-linked to RecA $A_{H s}$. The extent of the ATP crosslinking to $\operatorname{Rec}_{\mathrm{Hs}}$ was not altered by incubation with $\mathrm{Rec}_{\mathrm{Hs}}$ at concentrations of 2.5 or $10 \mu \mathrm{M}$ (Figure 2C), suggesting that ATP binding is not affected by the protein interaction. At high $\operatorname{Rec}_{\mathrm{Hs}}$ concentration (10 $\mu \mathrm{M}$; Figure $2 \mathrm{C}$, lanes 5 and 7 ), a shorter and weaker labeled band migrating close to the $\mathrm{Rec}_{\mathrm{Hs}}$ molecular weight was observed, suggesting that RecXHs has a low affinity ATP binding activity or nonspecific ATP binding. Cold ADP was 
added to the reactions as an ATP competitor.

\section{RecX inhibits ATP hydrolysis by RecA}

The quantification of RecA ATPase activity was used as an indirect measure of the amount of RecA bound to DNA. In the absence of agents that affect the intrinsic RecA ATPase activity, this has proven to be a reliable measure of RecA binding $(6,28,29)$. $\phi X 174$ circular ssDNA was used as the template to form the RecA filament since the RecA $A_{\mathrm{Hs}}$ protein did not possess ATPase activity in the absence of DNA or in the presence of $\phi X 174$ linear dsDNA at pH 7.5 (data not shown).

ATP hydrolysis by the $H$. seropedicae RecA protein in the presence of ssDNA was slightly less efficient than the $E$. coli RecA. Rec $\mathrm{X}_{\mathrm{Hs}}$ did not show any ATPase activity (Figure $3 A$ ), but inhibited RecA $A_{H s}$ ATPase activity in a concentrationdependent manner (Figure 3A): $10 \mu \mathrm{M}$ Rec $\mathrm{X}_{\mathrm{Hs}}$ inhibited $90 \%$ of the RecA $_{\mathrm{Hs}}$ ATPase activity.
The effect of the order of addition of the RecX protein on the ATPase activity of the RecA protein was also investigated. When RecX was added to the system after preincubation of RecA with ssDNA (RecA + ssDNA $\rightarrow$ RecX), the ATP hydrolysis rate was reduced by $35 \%$. When RecX was incubated with RecA before the addition of ssDNA ( $\operatorname{Rec} A+\operatorname{Rec} X \rightarrow$ ssDNA), the reduction was $50 \%$ (Figure $3 B)$. The reduction was even larger $(60 \%)$ when RecX was incubated together with RecA and ssDNA (RecA + RecX + ssDNA).

The pre-incubation of RecX with DNA before the addition of RecA (RecX + DNA $\rightarrow$ RecA) almost abolished ATP hydrolysis and this inhibition was partially reversed by the addition of excess ssDNA $(132 \mu \mathrm{M})$ together with RecA $(\operatorname{Rec} X+$ ssDNA $\rightarrow$ RecA + ssDNA) or 20 min after RecA (Figure $3 \mathrm{C}$ ). Furthermore, reducing the RecX concentration to $0.5 \mu \mathrm{M}$ caused reduction of the inhibition level $(20 \%$, contrasting with the $88 \%$ inhibition with $5 \mu \mathrm{M}$ Rec $\left.\mathrm{X}_{\mathrm{Hs}}\right)$. Ap-
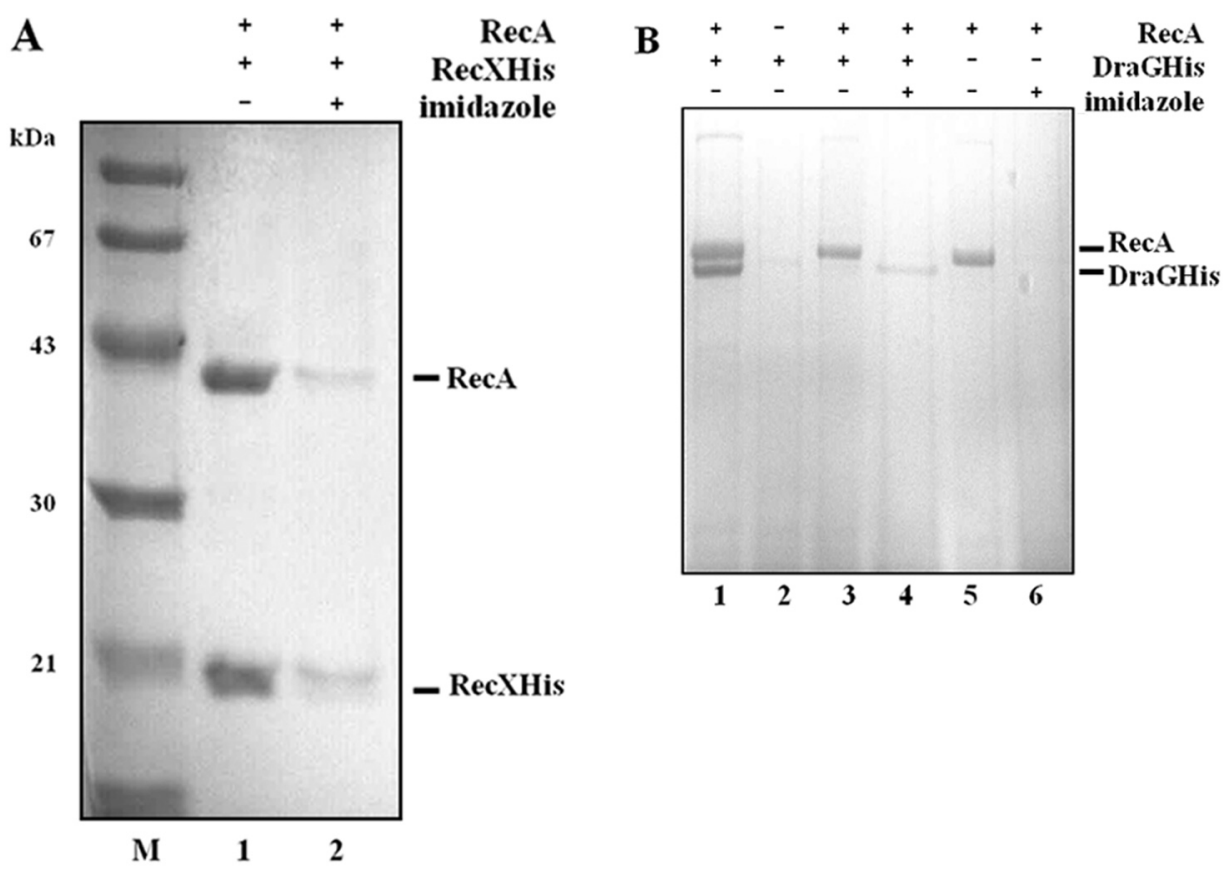

Figure 1. The binding of Herbaspirillum seropedicae RecA to RecX. The interaction between the $H$. seropedicae RecA and RecX proteins was determined by a Sepharose-Ni ${ }^{2+}$ bead immobilization assay as described in Methods. The HisTagged protein immobilized on $\mathrm{Ni}^{2+}$ beads was incubated with the native protein and then eluted with $0.5 \mathrm{M}$ imidazole. $A$, Lane $M=$ molecular weight markers; lane $1=$ native RecA $(4.2 \mu \mathrm{g})$ and RecXHis $(4.2 \mu \mathrm{g})$ control; lane 2 = fraction eluted with $0.5 \mathrm{M}$ imidazole from RecXHis-charged $\mathrm{Ni}^{2+}$ beads after the addition of native RecA. B, Lane $1=$ DraGHis $(4.2 \mu \mathrm{g})$ and native $\operatorname{RecA}(4.2 \mu \mathrm{g})$; lane 2 = washing fraction from DraGHis-charged $\mathrm{Ni}^{2+}$ beads; lane $3=$ washing fraction of the system DraGHis-Ni ${ }^{2+}$ beads after the addition of native RecA; lane $4=$ fraction eluted with $0.5 \mathrm{M}$ imidazole from DraGHis-charged $\mathrm{Ni}^{2+}$ beads after the addition of native RecA; lane 5 = native RecA (4.2 $\mu \mathrm{g}$ ); lane $6=$ fraction eluted with $0.5 \mathrm{M}$ imidazole from native RecA-charged $\mathrm{Ni}^{2+}$ beads. The histidinetagged proteins were immobilized on Sepharose-chelating FF beads $\left(\mathrm{Ni}^{2+}\right.$ beads, $\left.15 \mu \mathrm{L}\right)$ and washed with buffer $\mathrm{A}$ (10 mM Tris- $\mathrm{HCl}, \mathrm{pH} 8.0,50 \mathrm{mM} \mathrm{NaCl}$ and $1 \mathrm{mM} \mathrm{DTT}$ ) containing $5 \%$ glycerol in the presence or absence of $2.5 \mu \mathrm{M}(8.4 \mu \mathrm{g})$ of native RecA as indicated. The immobilized proteins were eluted with buffer $\mathrm{A}$ containing $5 \%$ glycerol and $0.5 \mathrm{M}$ imidazole. 


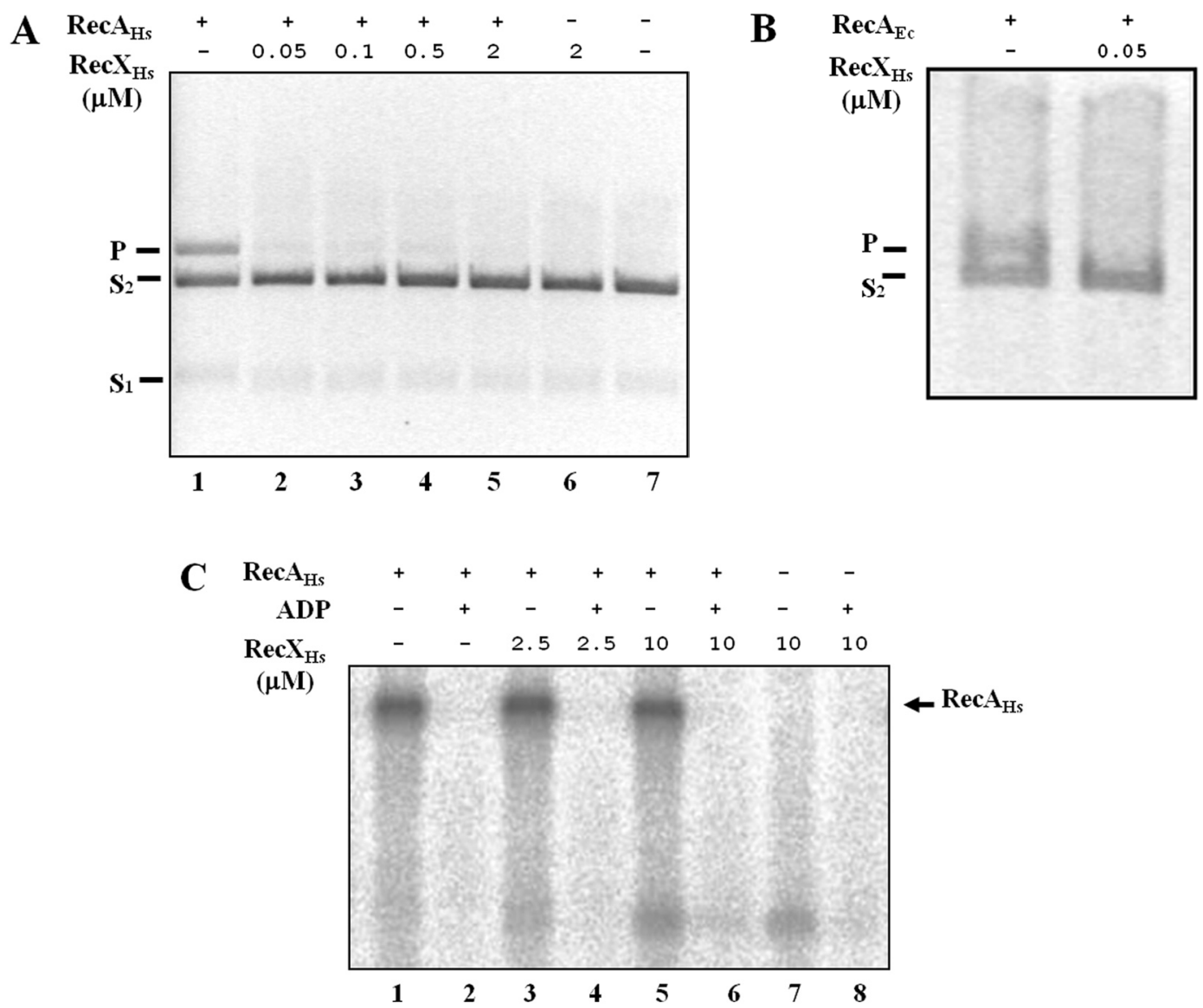

Figure 2. Inhibition by RecX of RecA-mediated DNA strand exchange and ATP binding. Effect of increasing concentrations of the $\mathrm{Rec}_{\mathrm{Hs}}$ protein on the DNA strand exchange mediated by Herbaspirillum seropedicae RecA $\left(\operatorname{Rec}_{H s}\right)(A)$ or Escherichia coli RecA (RecA $\left.A_{E c}\right)(B)$. Effect of RecX $X_{H s}$ on the RecA ATP-binding activity $(C)$. (+) indicates the presence and (-) the absence of the indicated components. $\mathrm{S} 1$ is circular ssDNA, S2 is linear dsDNA and $P$ is nicked circular dsDNA.

parently, RecX inhibits RecAATPase activity more efficiently when RecX is pre-incubated with ssDNA, indicating that the RecX-ssDNA binding might be important in the mechanism of inhibition of the RecA filament formation.

\section{Discussion}

In most bacterial species studied to date, including $H$. seropedicae, recX is found downstream and co-transcribed with the recA gene $(17,20,21)$, but exceptions to the typical recA-recX genomic organization are found including overlapping (16) or separated genes on the chromosome regulated by their own promoters (24; Table S1). A role for RecX as a negative regulator of RecA was initially hypothesized based on the observation that RecX is required to overcome the harmful effects of RecA overexpression in Pseudomonas aeruginosa (22), Mycobacterium smegmatis (23), Streptomyces lividans (17), X. oryzae pv. oryzae (18) and $H$. seropedicae (21). Such phenotype was not observed in $E$. coli and $D$. radiodurans recX mutants in which RecAoverexpression was not lethal $(20,26$; Table S1). Contrasting phenotypes were also found in $D$. radiodurans and $X$. oryzae pv. oryzae when the recX gene was deleted, resulting in constitutive expression and repression of $\operatorname{rec} A$, respectively $(26,18$; Table S1).

In this study, we show that RecX modulates negatively the RecA recombinase (Figure 2A) and ATPase activities in vitro (Figure $3 \mathrm{~A}$ ) without affecting its ATP binding activity (Figure 2B). Analyses of the effect of RecX $\mathrm{H}_{\mathrm{Hs}}$ on $\mathrm{Rec}_{\mathrm{Hs}}$ activities showed that a 30 -fold molar excess of the $H$. seropedicae RecX protein was necessary to inhibit completely RecA $_{\mathrm{Hs}}$ ATPase activity (Figure 3A). In E. coli, M. tuberculosis and $N$. gonorrhoeae, substoichiometric concentrations of RecX were capable to completely abolish homologous RecAATPase activity $(28,27,37)$ but higher levels of RecX were also required to inhibit RecA from $D$. radiodurans (26; Table S1). On the other hand, $H$. seropedicae RecA DNA strand exchange activity was inhibited by $\mathrm{Rec}_{\mathrm{Hs}}$ at 

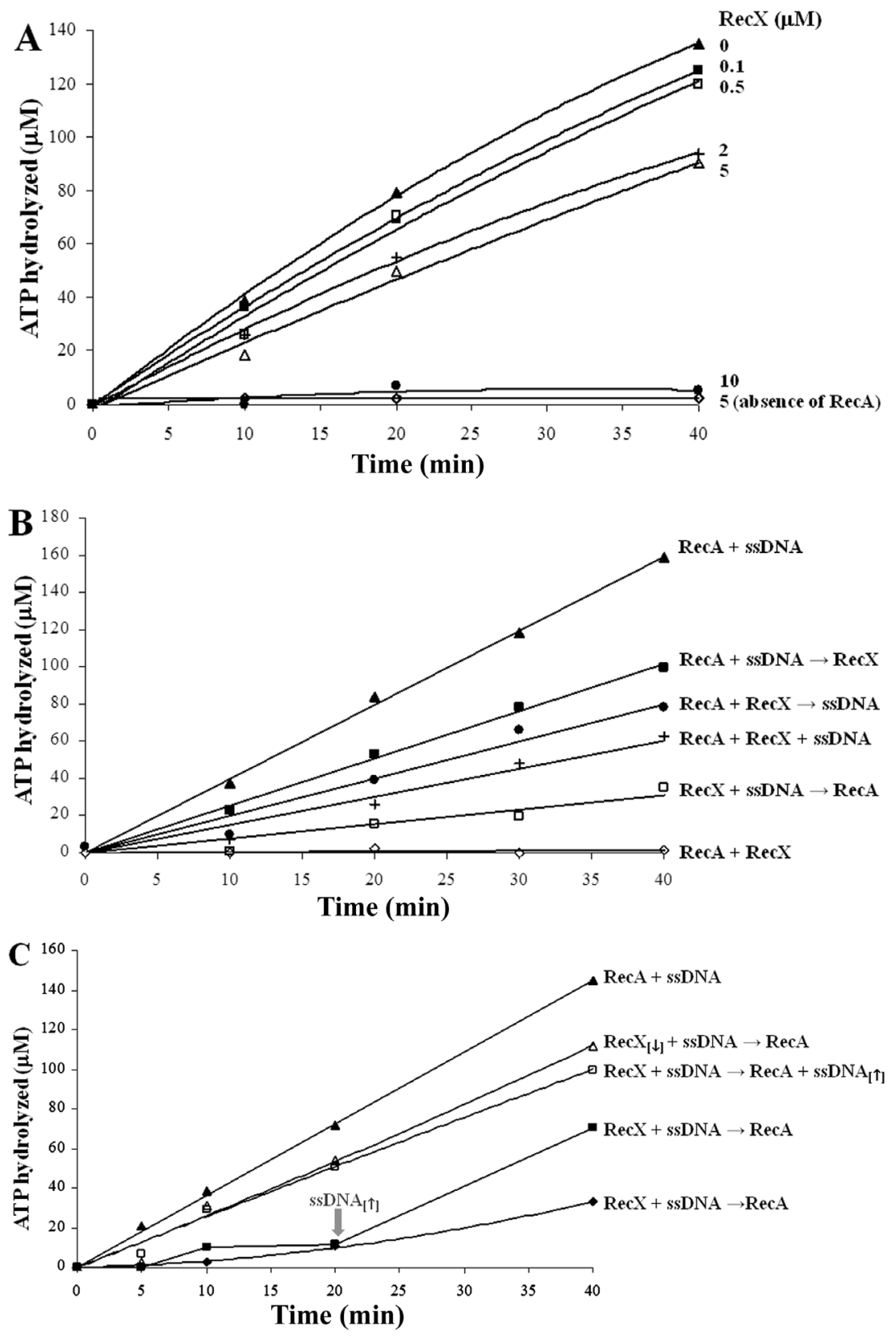

Figure 3. Effect of the Rec $\mathrm{X}_{\mathrm{Hs}}$ protein concentration $(A)$, the order of its addition $(B)$ and the effect of ssDNA $(C)$ on the ATP hydrolysis mediated by RecA $\mathrm{Hs}_{\mathrm{s}} . A$, The RecA $\mathrm{H}_{\mathrm{Hs}}$ protein, $\phi \mathrm{X} 174$ circular ssDNA and increasing concentrations of Rec $\mathrm{X}_{\mathrm{Hs}}$ protein $(0 \mu \mathrm{M}$, filled triangles; $0.1 \mu \mathrm{m}$, filled squares; $0.5 \mu \mathrm{m}$, open squares; $2 \mu \mathrm{m}$, crosses; $5 \mu \mathrm{m}$, open triangles; $10 \mu \mathrm{M}$, filled circles) were incubated in ATPase buffer at $37^{\circ} \mathrm{C}$ for 10 $\mathrm{min}$. After this period, the SSB protein and [ $\left.\alpha^{32} \mathrm{P}\right]-A T P$ were added. As a control without RecA, $5 \mu \mathrm{M}$ Rec $\mathrm{X}_{\mathrm{Hs}}$ was incubated with ssDNA (open lozenges). $B$, Two of the following components: $\phi X 174$ circular ssDNA, RecA $\mathrm{Hs}_{\mathrm{s}}$ and Rec $\mathrm{X}_{\mathrm{Hs}}$ proteins were pre-incubated in ATPase buffer at $37^{\circ} \mathrm{C}$ for $10 \mathrm{~min}$. After this period, the third component (RecX, sSDNA or RecA) was added together with the SSB protein and [a $\left.{ }^{32} \mathrm{P}\right]-A T P$ (filled squares, filled circles, open squares). Alternatively, all three components were pre-incubated together under the same conditions, before the addition of the SSB protein and [a $\left.{ }^{32} \mathrm{P}\right]-A T P$ after $10 \mathrm{~min}$ (crosses). As controls, RecA $\mathrm{Hs}_{\mathrm{Hs}}$ was incubated with ssDNA in the absence of RecX (filled triangles) or incubated with Rec $\mathrm{X}_{\mathrm{Hs}}$ in the absence of ssDNA (open lozenges). $C$, RecX $\mathrm{H}_{\mathrm{Hs}}(0.5$ or $5 \mu \mathrm{M}$ ) and $\phi \mathrm{X} 174$ circular ssDNA were pre-incubated in ATPase buffer at $37^{\circ} \mathrm{C}$ for $10 \mathrm{~min}$. After this period, RecA alone (filled lozenges, open triangles), RecA plus ssDNA (132 $\mu \mathrm{M}$, open squares) or RecA and then ssDNA ( $132 \mu \mathrm{M}$, added just $20 \mathrm{~min}$ later, as indicated by the gray arrow; filled squares) were added together with the SSB protein and [a $\left.{ }^{32} \mathrm{P}\right]-A T P$. The concentration of $\mathrm{Rec}_{\mathrm{Hs}}$ was unchanged and SSDNA $\mathrm{A}_{[\uparrow]}$ and RecX $\mathrm{X}_{[\downarrow]}$ indicate the following unusual concentrations: $132 \mu \mathrm{M}$ ssDNA and $0.5 \mu \mathrm{M}$ RecX, respectively. In all of the assays after the addition of [ ${ }^{32}$ P]-ATP (zero time), aliquots were collected and stopped. 
substoichiometric concentrations (Figure 2A), as reported for M. tuberculosis and $D$. radiodurans $(27,26)$. In contrast, in $E$. coli, stoichiometric levels of RecX were required to inhibit strand DNA exchange by RecA (28; Table S1). The affinities of RecX for ssDNA and dsDNA also vary among the different organisms. While ssDNA binding of E. coliand N. gonorrhoeae RecX is observed at ssDNA concentrations lower than $1 \mu \mathrm{M}$ (37), $\operatorname{RecX}_{\mathrm{Hs}}$ binds ssDNA only at higher concentrations ( $\geq 1$ $\mu \mathrm{M} ; 30)$. In sharp contrast, $M$. tuberculosis RecX did not show any DNA binding activity (27; Table S1).

The negative effect of $H$. seropedicae RecX on RecA activities may be partially due to their direct interaction as shown in Figure 1A. In vitro studies revealed that $\operatorname{RecX}$ and RecA from several organisms such as E. coli (25), $M$. tuberculosis (27) and $D$. radiodurans (26) interact with each other, and therefore the direct binding of these two proteins is functionally relevant (Table S1). However, to further investigate the mechanism of RecX action, the ATPase activity of $H$. seropedicae RecA was studied under several conditions. The $\mathrm{Rec}_{\mathrm{Hs}}$ protein has a low DNA-independent ATPase activity, which is not stimulated by dsDNA at $\mathrm{pH} 7.5$ as it was reported for the E. coli RecA protein (38). Addition of ssDNA greatly stimulated the ATPase activity. Interestingly, the inhibition of RecA $A_{\mathrm{Hs}}$ ATPase activity by $\mathrm{Rec} \mathrm{X}_{\mathrm{Hs}}$ was influenced by the order of addition of the proteins in a pattern suggesting competition between RecA and RecX for DNA binding. Previously, Drees et al. $(28,29)$ suggested that the RecX inhibition mechanism involved the binding of RecX to RecA filaments thus blocking the filament extension, a mechanism consistent with the observed interaction of the two proteins. However, if this RecX only interacted with the RecA filament, the same level of ATP hydrolysis by RecA should occur when RecX was pre-incubated with DNA before the addition of RecA and when RecX was incubated together with RecA and DNA. However, this was not observed: the inhibition of ATPase activity was strongest when RecX was pre-incubated with ssDNA, therefore before RecA filaments were formed on ssDNA(Figure 3B). We have shown previously that $\mathrm{Rec}_{\mathrm{Hs}}$ has ssDNA binding activity (30), which, together with the results reported here, strongly suggests that $\mathrm{Rec}_{\mathrm{Hs}}$ inhibits RecA filament formation by a mechanism involving direct interaction with RecA and also by controlling the availability of the ssDNA, thus inhibiting the nucleation of RecA or the extension of the RecA filament. This suggestion is strength-

\section{References}

1. Kuzminov A. Recombinational repair of DNA damage in Escherichia coli and bacteriophage lambda. Microbiol Mol Biol Rev 1999; 63: 751-813.

2. Friedberg EC, Walker GC, Siede W, Wood RD, Schultz RA, Ellenberger T. DNA repair and mutagenesis. 2 nd edn. Washington DC: ASM Press; 2006.

3. Goodman MF. Error-prone repair DNA polymerases in prokary- ened by the observation that the addition of excess ssDNA to the system overrides RecX inhibition of ATP hydrolysis (Figure $3 \mathrm{C}$ ). Since the concentration of ssDNA expressed in nucleotides was greater than the concentration of RecX, a mechanism whereby RecX inhibits RecA solely by direct protein-protein interaction would be insensitive to extra ssDNA being added to the reaction system. Detailed studies in $E$. coli have revealed that $\operatorname{RecX}$ acts by binding to the end of the growing RecA filament, thus limiting filament growth and leading to net disassembly (28). However, the observation that $\operatorname{Rec}_{\mathrm{Ec}_{\mathrm{c}}}$ competes with SSB implied that the mechanism of control of RecA activity by RecX in $E$. coli may involve RecX binding to both RecA and ssDNA (39), which is in agreement with our results.

The variety of recA-recX genomic organizations, recX mutant phenotypes, RecA ATPase and strand DNA exchange inhibition level by RecX, RecX ssDNA and dsDNA affinities suggests that specific mechanisms to control RecA activity operate in different bacteria. Furthermore, accessory protein may play an important role in the regulation of RecA activities. For example, in E. coli the RecF and Dinl proteins antagonize the negative modulation of $\operatorname{Rec} X(11,10)$. The absence of the recF, dinl, $\operatorname{din} B, \operatorname{rec} B C D, \operatorname{sbc} A, s b c C D$ genes, and the presence of a truncated umuC gene in the $H$. seropedicae genome (40) suggest that DNA recombination and repair systems of this bacteria and the control of RecA activities may present novel features.

The results presented here show that RecX of $H$. seropedicae negatively modulates the RecA strand exchange and ATPase activities but not ATP binding. The results also support the suggestion that RecX-ssDNA interactions are relevant for this negative regulatory activity of RecX in addition to protein-protein interactions.

\section{Supplementary material}

Table S1.

\section{Acknowledgments}

We are grateful to Roseli Prado, Julieta Pie, and Valter A. de Baura for technical assistance and Luciano F. Huergo for donating the DraG His-tagged protein. Research supported by CNPq, PRONEX, and SETI (Secretaria de Estado da Ciência, Tecnologia e Ensino Superior). otes and eukaryotes. Annu Rev Biochem 2002; 71: 17-50.

4. Lusetti SL, Cox MM. The bacterial RecA protein and the recombinational DNA repair of stalled replication forks. Annu Rev Biochem 2002; 71: 71-100.

5. Jiang Q, Karata K, Woodgate R, Cox MM, Goodman MF. The active form of DNA polymerase $\mathrm{V}$ is UmuD'(2)C-RecA-ATP. Nature 2009; 460: 359-363. 
6. Shan Q, Bork JM, Webb BL, Inman RB, Cox MM. RecA protein filaments: end-dependent dissociation from ssDNA and stabilization by RecO and RecR proteins. J Mol Biol 1997; 265: 519-540.

7. Bork JM, Cox MM, Inman RB. RecA protein filaments disassemble in the 5' to 3 ' direction on single-stranded DNA. J Biol Chem 2001; 276: 45740-45743.

8. Lindsley JE, Cox MM. Assembly and disassembly of RecA protein filaments occur at opposite filament ends. Relationship to DNA strand exchange. J Biol Chem 1990; 265: 9043-9054.

9. Bianco PR, Kowalczykowski SC. RecA protein. In: John Wiley \& Sons (Editor), Encyclopedia of life sciences. Chichester: John Wiley \& Sons, Ltd.; 2005. p 1-9.

10. Lusetti SL, Drees JC, Stohl EA, Seifert HS, Cox MM. The Dinl and RecX proteins are competing modulators of RecA function. J Biol Chem 2004; 279: 55073-55079.

11. Lusetti SL, Hobbs MD, Stohl EA, Chitteni-Pattu S, Inman RB, Seifert HS, et al. The RecF protein antagonizes RecX function via direct interaction. Mol Cell 2006; 21: 41-50.

12. Drees JC, Chitteni-Pattu S, McCaslin DR, Inman RB, Cox MM. Inhibition of RecA protein function by the RdgC protein from Escherichia coli. J Biol Chem 2006; 281: 4708-4717.

13. Spies M, Kowalczykowski SC. The RecA binding locus of RecBCD is a general domain for recruitment of DNA strand exchange proteins. Mol Cell 2006; 21: 573-580.

14. Petrova V, Chitteni-Pattu S, Drees JC, Inman RB, Cox MM. An SOS inhibitor that binds to free RecA protein: the PsiB protein. Mol Cell 2009; 36: 121-130.

15. Cox MM. Regulation of bacterial RecA protein function. Crit Rev Biochem Mol Biol 2007; 42: 41-63.

16. Papavinasasundaram KG, Movahedzadeh F, Keer JT, Stoker NG, Colston MJ, Davis EO. Mycobacterial recA is cotranscribed with a potential regulatory gene called recX. Mol Microbiol 1997; 24: 141-153.

17. Vierling S, Weber T, Wohlleben W, Muth G. Transcriptional and mutational analyses of the Streptomyces lividans recX gene and its interference with RecA activity. J Bacteriol 2000; 182: 4005-4011.

18. Sukchawalit $R$, Vattanaviboon $P$, Utamapongchai $S$, Vaughn $G$, Mongkolsuk S. Characterization of Xanthomonas oryzae pv. oryzae rec $X$, a gene that is required for high-level expression of recA. FEMS Microbiol Lett 2001; 205: 83-89.

19. Yang $Y C$, Hsu CH, Chou CP, Yang MK. Genetic organization of the lexA, recA and recX genes in Xanthomonas campestris. FEMS Microbiol Lett 2002; 209: 149-154.

20. Pages V, Koffel-Schwartz N, Fuchs RP. recX, a new SOS gene that is co-transcribed with the recA gene in Escherichia coli. DNA Repair 2003; 2: 273-284.

21. Galvao CW, Pedrosa FO, Souza EM, Yates MG, Chubatsu LS, Steffens MB. The recX gene product is involved in the SOS response in Herbaspirillum seropedicae. Can J Microbiol 2003; 49: $145-150$.

22. Sano $Y$. Role of the recA-related gene adjacent to the recA gene in Pseudomonas aeruginosa. J Bacteriol 1993; 175: 24512454.

23. Papavinasasundaram KG, Colston MJ, Davis EO. Construction and complementation of a recA deletion mutant of Mycobacterium smegmatis reveals that the intein in Mycobacterium tuberculosis recA does not affect RecA function. Mol Microbiol 1998; 30: 525-534

24. Stohl EA, Seifert HS. The recX gene potentiates homologous recombination in Neisseria gonorrhoeae. Mol Microbiol 2001; 40: 1301-1310.

25. Stohl EA, Brockman JP, Burkle KL, Morimatsu K, Kowalczykowski SC, Seifert HS. Escherichia coli RecX inhibits RecA recombinase and coprotease activities in vitro and in vivo. J Biol Chem 2003; 278: 2278-2285.

26. Sheng D, Liu R, Xu Z, Singh $P$, Shen $B$, Hua Y. Dual negative regulatory mechanisms of RecX on RecA functions in radiation resistance, DNA recombination and consequent genome instability in Deinococcus radiodurans. DNA Repair 2005; 4: 671-678.

27. Venkatesh R, Ganesh N, Guhan N, Reddy MS, Chandrasekhar T, Muniyappa K. RecX protein abrogates ATP hydrolysis and strand exchange promoted by RecA: insights into negative regulation of homologous recombination. Proc Natl Acad Sci U S A 2002; 99: 12091-12096.

28. Drees JC, Lusetti SL, Chitteni-Pattu S, Inman RB, Cox MM. A RecA filament capping mechanism for RecX protein. Mol Cell 2004; 15: 789-798

29. Drees JC, Lusetti SL, Cox MM. Inhibition of RecA protein by the Escherichia coli RecX protein: modulation by the RecA C terminus and filament functional state. J Biol Chem 2004; 279: 52991-52997.

30. Galvao CW, Pedrosa FO, Souza EM, Yates MG, Chubatsu LS, Steffens MB. Expression, purification, and DNA-binding activity of the Herbaspirillum seropedicae RecX protein. Protein Expr Purif 2004; 35: 298-303.

31. Steffens MB, Rigo LU, Funayama S, Souza EM, Machado HB, Pedrosa FO. Cloning of a recA-like gene from the diazotroph Herbaspirillum seropedicae strain Z78. Can J Microbiol 1993; 39: 1096-1102.

32. Sambrook J, Fritsch EF, Maniatis T. Molecular cloning: a laboratory manual. Cold Spring Harbor: Cold Spring Harbor Laboratory Press; 1989.

33. Steffen SE, Bryant FR. Purification and characterization of the single-stranded DNA binding protein from Streptococcus pneumoniae. Arch Biochem Biophys 2001; 388: 165-170.

34. Schumacher J, Zhang X, Jones S, Bordes P, Buck M. ATPdependent transcriptional activation by bacterial PspF AAA+ protein. J Mol Biol 2004; 338: 863-875.

35. Laemmli UK. Cleavage of structural proteins during the assembly of the head of bacteriophage T4. Nature 1970; 227: 680-685.

36. Bochner BR, Ames BN. Complete analysis of cellular nucleotides by two-dimensional thin layer chromatography. $J$ Biol Chem 1982; 257: 9759-9769.

37. Gruenig MC, Stohl EA, Chitteni-Pattu S, Seifert HS, Cox MM. Less is more: Neisseria gonorrhoeae RecX protein stimulates recombination by inhibiting RecA. J Biol Chem 2010; 285: 37188-37197.

38. Weinstock GM, McEntee K, Lehman IR. Hydrolysis of nucleoside triphosphates catalyzed by the recA protein of Escherichia coli. Steady state kinetic analysis of ATP hydrolysis. J Biol Chem 1981; 256: 8845-8849.

39. Baitin DM, Gruenig MC, Cox MM. SSB antagonizes RecX-RecA interaction. J Biol Chem 2008; 283: 14198-14204.

40. Pedrosa FO, Monteiro RA, Wassem R, Cruz LM, Ayub RA, Colauto NB, et al. Genome of Herbaspirillum seropedicae strain SmR1, a specialized diazotrophic endophyte of tropical grasses. PLoS Genet 2011; 7: e1002064. 